\title{
ANALISA FAKTOR-FAKTOR YANG MEMPENGARUHI KEPUTUSAN MAHASISWA MEMILIH KULIAH DI SEKOLAH TINGGI ILMU EKONOMI INDONESIA (STEI) JAKARTA
}

\author{
Yusuf Suhardi ${ }^{1}$, Meita Pragiwani ${ }^{2}$ \\ Sekolah Tinggi Ilmu Ekonomi Indonesia (STEI) Jakarta \\ Jl. Kayu Jati Raya No. 11, Rawamangun, Jakarta \\ suhardi.1960.ys@gmail.com ${ }^{1}$, meitasoetopo@gmail.com ${ }^{2}$
}

\begin{abstract}
This research was conducted at Sekolah Tinggi Ilmu Ekonomi Indonesia (STEI) Jakarta. The study population is STEI New Student of academic year 2016/2017 totaling 1,062 people, sampling using Slovin amounted to 295 students of STEI in S1 Accounting Study Program, S1 Management, Accounting D3 and D3 of Trade Management. Sampling technique with random sampling or random. This research uses descriptive analysis method. The result of validity test of internal factor and external factor $r$-count all bigger than $r$-table mean all statement is valid. Reliability test results show all statements both internal and external realibel because crobach Alpha is 0.780 and 0.729 above 0.6. The results show that STEI Student Candidates from the beginning of the majority aspire to become an economics graduate. Most of the respondents believe that STEI graduates will get a good job. The majority respondents felt they had a talent in the field of economics. The majority enter STEI because STEI accreditation is $B$ and in deciding place of college majority factor of location that is close to campus, besides because of tuition in STEI is affordable. Suggestion of lectures at STEI which is dominant is advice from parents then from friends. The majority of STEI Student Candidates receive information from brochures and banners, receive very little information from advertisements on newspapers, radio, television, internet and STEI presentations at school
\end{abstract}

Keywords: Decision, Motivation, Higher Education

\section{PENDAHULUAN}

Dalam penelitian ini melakukan analisa faktor-faktor yang mempengaruhi keputusan mahasiswa memilih kuliah di STEI. Memilih perguruan tinggi merupaka keputusan seseorang sesuai dengan tingkat kebutuhannya. Pilihan dapat terbentuk melalui pola pikir yang didasari oleh beberapa alasan, antara lain pengalaman yang diperolehnya, merasakan kepuasan dalam memilih 
perguruan tinggi dan merasakan kecocokan dengan pilihan tersebut, maka akan menperjuangkan pilihannya sehingga turun-temurun,

Calon konsumen adalah orang yang hati hati dalam memilih baik produk maupun jasa. Sehingga ada benarnya sebagai produsen baik jasa maupun produk akan sangat hati-hati berhadapan dengan konsumen. Apabila menempatkan konsumen sebagai orang biasa maka semangat melayani akan rendah sehingga konsumen tidak akan tertarik pada penjual seperti itu. Konsumen juga banyak yang pinter yang berorientasi pada kwalitas serta harga yang terjangkau, orang ini akan membandingkan beberapa produsen yang punya kelebihan baru pembelian.

Kasmir (2004) yang menyatakan bahwa konsumen pada saat ini cenderung lebih bersifat cerdik, suka memilih, lebih menuntut, mempelajari dengan baik produk atau layanan yang ditawarkan, kesetiaannya rendah, sangat peduli terhadap harga, serta mencari nilai yang tertinggi.

Sekolah Tinggi Ilmu Ekonomi Indonesia senantiasa secara terus menerus meningkatkan bauran pemasarannya yaitu produc berupa perbaikan proses belajar mengajar, kurikulum dan sebaginya. Price yaitu STEI membebankan uang kuliah terendah dari perguruan tinggi setingkat di Jakarta, supaya lebih kompetitif.. Place atau lokasi STEI berada di lokasi yang strategis yaitu Rawamangun Jakarta Timur dan kota bekasi untuk menampung mahasiswa yang bertempat tinggal di Bekasi.

Kegiatan promosition dengan berbagai upaya baik iklan, presentase ke sekolahsekolah, brosur dicetak ribuan lembar dan sebagainya. People diselenggarakan dengan tenaga dosen kwalifikasi pendidikan Doktor dan Magister serta karyawan yang profesional. Physical evidence yaitu penampilan gedung dan fasilitas penunjang sangar baik dan process yaitu pelaksanan proses belajar mengajar dilaksanakan dengan baik sesuai dengan pedoman yang diatur oleh pemerintah.

Identifikasi masalah yaitu gejala yang perlu mendapatkan perhatian di STIE Indonesia ini adalah faktor sbb:Jumlah pendaftar mahasiswa baru dari tahun ke tahun relatif tetap kurang peningkatan secara signifikan. Lokasi kampus tidak berada di jalan utama tetapi berada di jalan biasa sehingga kurang diketahui olek masyarakat luas. Sarana perparkiran untuk kendaraan dosen dan mahasiswa kurang memadai, sehingga dirasakan kurang nyaman dalam memarkir kendaraan Civitas Akadmika. STEI memperoleh akreditasi B semua program studi baik D3, S1 dan S2 dari BAN PT sedangkan pesaing banyak yang sudah akreditasi A.

Tujuan penelitian ini adalah: Untuk mengetahui faktor-faktor apa saja yang mempengaruhi mahasiswa untuk mengikuti kuliah di Sekolah Tinggi Ilmu Ekonomi Indonesia (STEI). Juga mana saja yang paling dominan dari berbagai faktor tersebut. 
Hasil penelitian ini diharapkan dapat diperoleh kegunaan penelitian adalah : Secara akademis diharapkan bermanfaat bagi ilrnu pengetahuan khususnya tengtang motivasi konsumen yang berkaitan dengan pengambilan keputusan untuk memutuskan suatu pilihan. Secara praktis penelitian ini diharapkan bermanfaat bagi pembuat kebijakan di STEI untuk meningkatkan proses pendidikan tinggi baik berupa fisik maupuan non fisik. Hasil penelitian ini juga bermanfaat bagi dosen, pustakawan, laboran, karyawan, dan mahasiswa dalam meningkatkan kinerja sesuai dengan fungsi dan tugas masing-masing.

Ruang lingkup penelitian ini adalah seluruh Mahasiswa Baru Tahun Akademik 2016/2017 Sekolah Tinggi Ilmu Ekonomi Indonesia (STEI) yang sedang menempuh pendidikan pada Prodi S1 Akuntansi, D3 Akuntansi, S1 Manajemen dan D3 Manajemen Perdagangan yang jumlah populasinya sebesar 1.062 orang. Berdasarkan hal tersebut maka penelitian ini berjudul " Analisa Faktor-Faktor Yang Mempengaruhi Keputusan Mahasiswa Memilih Kuliah Di Sekolah Tinggi Ilmu Ekonomi Indonesia (STEI) Jakarta.

\section{LANDASAN TEORI}

Dikemukakan oleh Zeithaml dan Bitner yang dikutif oleh Ratih Hurriyati (2005:49) bauran pemasaran jasa terdiri dari 7P yaitu product, price, promotion, place, people, process dan physical evidence. Definisi bauran pemasaran menurut Kotler (2000) sebagai berikut : Bauran pemasaran adalah sekumpulan perangkat atau alat pemasaran taktis yang dapat dikendalikan dan dipadukan oleh perusahaan untuk menghasilkan respon yang diinginkan dalam pasar sasaran. Dengan demikian memasarkan suatu produk diperlukan bauran pemasaran yaitu strategi mencampur kegiatan-kegiatan marketing, agat terdapat kombinasi maksimal dalam upaya mencapai hasil yang paling memuaskan.

Selanjutnya Booms dan Bitner (dalam Kotler 2000, 434) mengemukakan konsep bauran pemasaran tradisional (tradisional marketing mix) yang terdiri dari atas komponen : Product, Price, Place, dan Promotion (4Ps) sedangkan untuk pemasaran jasa menyarankan tambahan komponen : People, Physical Evidence, dan Process (3Ps). Menurut Zeithalm (2000, 18-21) setiap unsur dari bauran pemasaran jasa tersebut saling berhubungan dan saling bergantung antara satu dengan lainnya, yang disusun sesuai dengan karakteristik segmen pasar yang dituju. Philip Kotler $(2005 ; 181)$ bauran pemasaran dapat diklasifikasikan menjadi 7P (Product, Price, Place, Promotion, People, Physical Evidence, dan Process).

Kotler (2004: 8) mengemukakan bahwa pemasaran jasa pendidikan merupakan suatu proses sosial dan manajerial, baik oleh individu atau kelompok, untuk mendapatkan apa yang dibutuhkan dan diinginkan oleh lembaga pendidikan melalui penciptaan penawaran dengan pihak lain. Sasaran 
pemasaran jasa pendidikan menurut Davies \& Ellison, (Benty, 2001: 12) Seluruh sasaran apabila dikelompokkan terpusat dalam sasaran pokok (disebut "pasar" dalam dunia usaha) yaitu sasaran/ pasar internal dan eksternal artinya sasaran internal adalah dosen, mahasiswa dan staf yang yang terkait dengan perguruan tinggi beserta orangtua mereka, sasaran internal ini sering disebut civitas akademika

Kotler \& Amstrong (2001) menyatakan bahwa konsumen membuat pilihan pembelian berdasarkan persepsi mereka terhadap nilai yang melekat pada berbagai produk dan jasa. Nilai pelanggan merupakan selisih antara nilai yang diperoleh pelanggan dengan memiliki dan menggunakan produk, dengan biaya yang dikeluarkan untuk memperoleh produk tersebut. Sehingga total nilai pelanggan merupakan total selisih antara nilai yang diperoleh pelanggan dengan total biaya yang mereka keluarkan untuk suatu produk dan jasa yang mereka beli.

Keputusan pembelian merupakan keputusan konsumen untuk membeli suatu produk setelah sebelumnya memikirkan tentang layak tidaknya membeli produk itu dengan mempertimbangkan informasi - informasi yang ia ketahui dengan realitas tentang produk itu setelah ia menyaksikannya. Hasil dari pemikiran itu dipengaruhi kekuatan kehendak konsumen untuk membeli sebagai alternative Zeithalm (Nugroho Setiadi, 2002).

Menurut (Assael, 1998) bahwa minat untuk membeli ulang menunjukkan keinginan pelanggan untuk melakukan pembelian ulang. Banyak sekali faktor yang mempengaruhi konsumen dalam melakukan pembelian ulang yang dikonsumsinya, termasuk kualitas layanan pada saat dan sesudah pembelian suatu produk barang atau jasa. Istilah "need arousal" atau oleh penulis lain disebut "problem recognition" adalah proses pengambilan keputusan oleh konsumen untuk melakukan pembelian suatu produk yang diawali oleh adanya suatu kesadaran atas pemenuhan kebutuhan/keinginan.

Keputusan pembelian merupakan sikap seseorang untuk membeli atau menggunakan suatu produk baik berupa barang atau jasa yang telah diyakini akan memuaskan dirinya dan kesediaan menanggung resiko yang mungkin ditimbulkanya. Keputusan pembelian yang diambil oleh pembeli sebenarnya merupakan kumpulan dari sejumlah keputusan yang terorganisir (Kotler, 2008:170). Menurut Schiffman dan Kanuk dalam Sumarwan (2004:289) mendefinisikan suatu keputusan sebagai pemilihan suatu tindakan dari dua atau lebih pilihan alternatif. Seorang konsumen yang hendak melakukan pilihan maka ia harus memiliki pilihan alternatif.

Seperti dijelaskan oleh Marx \& Tombouch bahwa motivasi sebagai daya dorong dalam beroperasinya mesin gasoline (Riduwan, 2005:31). Bahwa motivasi sebagai penggerak atau pendorong bagi terbentuknya sebuah upaya tertentu yang dilakukan manusia untuk mencapai tujuan yang diinginkannya. Sebagai manusia yang berada dalam masyarakat maju yang menganut 
nilai-nilai modern maka setiap anggota masyarakat tersebut akan berupaya untuk menyesuaikan dengan nilai-nilai modern dan keinginan yang dikenakan pada dirinya.

Pengertian Motivasi dapat diartikan sebagai latar belakang atau sebab-sebab yang menjadi pendorong tindakan seseorang (M.Sastrapradja, 1981:330). Memilih STEI tempat kuliah tidak terlepas dari dorongan atau motivasi. Motivasi adalah dorongan yang timbul pada diri seseorang secara sadar atau tidak sadar untuk melakukan suatu tindakan dengan tujuan tertentu Seperti usaha untuk masuk perguruan tinggi yang dapat menyebabkan seseorang melakukan sesuatu karena ingin mencapai tujuan-tujuan tersebut. Motivasi diartikan sebagai dorongan yang memberikan semangat kepada diri seseorang untuk dapat mengerjakan suatu hal dengan baik

\section{PENELITIAN TERDAHULU}

\section{Tebel 1 : Penelitian Terdahulu}

\begin{tabular}{|c|c|c|c|c|c|}
\hline No & Peneliti & Judul & Variabel & Alat Analisis & Hasil \\
\hline 1 & $\begin{array}{l}\text { Hanny Hafiar, S. } \\
\text { Yanti Setianti, S. } \\
\text { Nurmaya } \\
\text { Prahatmaja }\end{array}$ & $\begin{array}{l}\text { Pembukaan Jalur } \\
\text { Saringan Masuk } \\
\text { Universitas } \\
\text { Padjadjaran (Smup) } \\
\text { Dalam Menumbuhkan } \\
\text { Minat } \\
\text { Melanjutkan Studi Ke } \\
\text { Perguruan Tinggi Pada } \\
\text { Siswa Smun 1 Tarogong } \\
\text { Garut }\end{array}$ & $\begin{array}{ll}\text { 1. } & \text { Alasan mengikuti jalur } \\
& \text { smup } \\
\text { 2. Persiapan mengikuti } \\
\text { 3. ujian jalur smup } \\
\text { 4. Motivasi melanjutkan } \\
\text { studi } \\
\text { 5. Tanggapan mengenai } \\
\text { smup }\end{array}$ & $\begin{array}{l}\text { Penelitian ini } \\
\text { menggunakan } \\
\text { metode } \\
\text { deskriptif }\end{array}$ & $\begin{array}{l}\text { Motivasi yang dimiliki untuk } \\
\text { melanjutkan studi ke perguruan tinggi } \\
\text { cukup tinggi, hal ini terlihat dari } \\
\text { bervariasinya faktor pendorong untuk } \\
\text { melanjutkan studi serta berbagai upaya } \\
\text { yang dilakukan untuk mengikuti jalur } \\
\text { SMUP. Selain itu tanggapan terhadap } \\
\text { SMUP dan proses sosialisasinya cukup } \\
\text { positif. }\end{array}$ \\
\hline 2 & $\begin{array}{l}\text { Lucia Suhartati } \\
\text { Rahayu, Abu } \\
\text { Asyari, } \\
\text { Rosmawati }\end{array}$ & $\begin{array}{l}\text { Analisis preferensi siswa } \\
\text { melanjutkan ke sma } \\
\text { santa maria kecamatan } \\
\text { sail kota pekanbaru } \\
\text { tahun pelajaran } \\
\text { 2014/2015 }\end{array}$ & $\begin{array}{ll}\text { 1. } & \text { Mendapat pekerjaan } \\
\text { yang layak, } \\
\text { 2. Ingin melanjutkan ke } \\
\text { perguruan tinggi, } \\
\text { 3. Karena atas persetujuan } \\
\text { orang tua, } \\
\text { 4. Ekonomi orangtua } \\
\text { menunjang, mendalami } \\
\text { ilmu } \\
\text { kategori preferensi } \\
\text { internal siswa }\end{array}$ & $\begin{array}{l}\text { Penelitian ini } \\
\text { adalah adalah } \\
\text { penelitian } \\
\text { deskriptif. }\end{array}$ & $\begin{array}{l}\text { Faktor internal yang menjadi preferensi } \\
\text { siswa memilih ke SMA adalah karena } \\
\text { ingin mendapat pekerjaan yang layak, } \\
\text { sesuai dengan minat, atas kemauan } \\
\text { sendiri, serta ingin melanjutkan ke } \\
\text { perguruan tinggi, (b) faktor eksternal } \\
\text { yang menjadi preferensi siswa memilih } \\
\text { ke SMA adalah karena atas persetujuan } \\
\text { orang tua, ekonomi orangtua } \\
\text { menunjang, mendalami ilmu yang } \\
\text { bersifat umum, (c) kategori preferensi } \\
\text { internal siswa memilih ke SMA berada } \\
\text { pada kategori tinggi sebesar } 70,44 \%,(d) \\
\text { ) kategori preferensi eksternal siswa } \\
\text { memilih ke SMA berada pada kategori } \\
\text { sedang sebesar } 62,89 \% \text {. }\end{array}$ \\
\hline 3 & $\begin{array}{l}\text { Ni Ketut Eka } \\
\text { Yulianti \& } \\
\text { Samuel S. } \\
\text { Patampang }\end{array}$ & $\begin{array}{l}\text { Minat Siswa Kelas Xii } \\
\text { Sma Negeri } 1 \text { Bolano } \\
\text { Lambunu Untuk } \\
\text { Melanjutkan Studi } \\
\text { Ke Jenjang Perguruan } \\
\text { Tinggi }\end{array}$ & $\begin{array}{l}\text { Faktor diri } \\
\text { siswa sendiri, } \\
\text { Faktor masa depan, Faktor } \\
\text { lingkungan sekolah, } \\
\text { Faktor lingkungan } \\
\text { masyarakat dan Faktor } \\
\text { dorongan dari orang tua. }\end{array}$ & $\begin{array}{l}\text { Metode } \\
\text { penelitian yang } \\
\text { digunakan } \\
\text { adalah } \\
\text { kualitatif. }\end{array}$ & $\begin{array}{l}\text { Minat siswa kelas XII SMA Negeri } 1 \\
\text { Bolano Lambunu melanjutkan } \\
\text { studi ke jenjang perguruan tinggi sudah } \\
\text { cukup baik, dengan hasil persentasi } \\
76,32 \% \text {. Adapun faktor yang } \\
\text { mempengaruhi yaitu diri siswa sendiri, } \\
\text { faktor } \\
\text { masa depan, faktor lingkungan sekolah, } \\
\text { faktor lingkungan masyarakat dan } \\
\text { faktor dorongan dari orang tua dan } \\
\text { faktor ekonomi keluarga. }\end{array}$ \\
\hline
\end{tabular}




\begin{tabular}{|c|c|c|c|c|c|}
\hline 4 & $\begin{array}{l}\text { Rusdiana Husaini, } \\
\text { Siti Shalihah, } \\
\text { Ardian Trio W } \\
\mathbf{2 0 1 5}\end{array}$ & $\begin{array}{l}\text { Motivasi Mahasiswa } \\
\text { Pgmi Dalam Memilih } \\
\text { Jurusan Pgmi Fakultas } \\
\text { Tarbiyah Dan Keguruan } \\
\text { Iain Antasari } \\
\text { Banjarmasin }\end{array}$ & $\begin{array}{l}\text { (1) motivasi menjadi guru ; } \\
\text { (2) motivasi menambah ilmu } \\
\text { pengetahuan agama (3) } \\
\text { motivasi menyenangi anak- } \\
\text { anak. (4) motivasi menuruti } \\
\text { kehendak orang tua; dan (5) } \\
\text { motivasi karena tidak lulus } \\
\text { dijurusan lain. }\end{array}$ & $\begin{array}{l}\text { Penelitian } \\
\text { deskriptif } \\
\text { eksploratif, } \\
\text { yaitu penelitian } \\
\text { dengan model } \\
\text { survey yang } \\
\text { mendeskripsika } \\
\text { n suatu gejala, } \\
\text { peristiwa, } \\
\text { kejadian yang } \\
\text { terjadi pada saat } \\
\text { sekarang. }\end{array}$ & $\begin{array}{l}\text { Motivasi mahasiswa PGMI dalam } \\
\text { memilih jurusan yaitu: Motivasi } \\
\text { intrinsik merupakan keinginan dicita- } \\
\text { citakan sejak di sekolah dasar, terdiri } \\
\text { dari: motivasi menjadi guru ketika sudah } \\
\text { lulus di sekolah } \\
\text { menengah; motivasi menambah ilmu } \\
\text { pengetahuan agama dan umum; dan } \\
\text { motivasi menyenangi anak-anak. Dan } \\
\text { Motivasi ekstrinsik terdiri dari: motivasi } \\
\text { menuruti kehendak orang tua; dan } \\
\text { motivasi karena tidak lulus dijurusan } \\
\text { lain. }\end{array}$ \\
\hline
\end{tabular}

\section{METODE PENELITIAN}

\section{Populasi dan Sampel}

Jumlah populasi adalah seluruh Mahasiswa Baru STEI Tahun Akademik 2016/2017 Program Studi : S1 Akuntansi, S1 Manajemen, D3 Akuntansi dan D3 Manajemen Perdagangan yang berjumlah 1.062 orang. Sampel diambil menggunakan model Slovin (Sevilla et. al., 1993), sebagai berikut:

$$
n=\frac{N}{1+N e^{2}}
$$

dimana

$n$ : jumlah sampel

$\mathrm{N}$ : jumlah populasi

e: batas toleransi kesalahan (error tolerance)

jadi sampel adalah sbb :

$$
n=1.062 / 1+1.062 \times 0,05=294,6=295 \text { orang }
$$

Teknik sampling dilakukan dengan random sampling atau acak yaitu kepada seluruh Mahasiswa Baru STEI.

Penelitian ini menggunakan metode deskriptif yaitu metode yang bertujuan memaparkan situasi atau peristiwa (Rakhmat, 2001:24). Jenis penelitian ini merupakan jenis penelitian deskriptif kualitatif. Zuriah (2007: 92) menjelaskan bahwa penelitian deskriptif kualitatif adalah salah satu prosedur penelitian yang menghasilkan data deskriptif berupa ucapan atau tulisan dan perilaku orang-orang yang diamati.

\section{ANALISIS DAN PEMBAHASAN \\ Validitas Faktor Internal dan Eksternal}


Hasil perhitungn menggunakan SPSS versi 23 bahwa angket yang diberikan kepada responden semua pertanyaan faktor internal uji validitas menunjukan hasilnya semuanya valid, artinya seperti $r$ hitung lebih besar dari $t$ tabel seperti pertanyaan no 1 bahwa $t$ hit 0,652 sedangkan $\mathrm{t}$ tabel hanya 0,114 . Begitu juga pernyataan no 2 yaitu $\mathrm{t}$ hit 0,733 lebih besar dari t tabel hanya 0,114 sampai pertanyaan no 4 .

Hasil perhitungan SPSS versi 23 menunjukan faktor eksternal sebanyak 21 pertanyaan seluruhnya valid hal ini misal terlihat pada $r$ hitung lebih besar dari $r$ tabel seperti pertanyaan nomor $1 \mathrm{r}$ hitung 0,285 sedangkan $\mathrm{r}$ tabel hanya sebesar 0,114 . Pertanyaan nomor 20 bahkan $\mathrm{r}$ hitung sebesar 0,636 sedangkan $r$ tabel tetap 0,114 .

\section{Reliabilitas Faktor Internal dan Eksternal}

Data SPSS untuk Uji reliabilitas terbukti faktor internal cronbach alpha nya sebesar 0,780 artinya bahwa lima faktor internal lebih dari 0,6. Dengan demikian berarti pernyataan reliabel artinya tingkat konsistensi alat ukur dapat memberikan hasil relatif tidak berbeda apabila dilakukan pengukuran kembali atau berulang.

Data SPSS untuk Uji reliabilitas terbukti faktor eksternal cronbach alpha nya sebesar 0,729 artinya bahwa 21 faktor eksternal lebih dari 0,6. Dengan demikian berarti pertanyaan reliabel artinya tingkat konsistensi alat ukur dapat memberikan hasil relatif tidak berbeda apabila dilakukan pengukuran berulang. Artinya keajegan pengukuran.

\section{HASIL PENELITIAN}

Hasil penelitian yang dilakukan terhadap 295 Mahasiswa STEI adalah sebagai berikut

Tabel 2

Hasil Penelitian

\begin{tabular}{|c|c|c|c|c|}
\hline No. Pernyataan & Tidak Setuju & Netral & Setuju & Sampel/Prosen \\
\hline A.Faktor Internal & & & & 295 \\
\hline 1 & 40 & 158 & $33 \%$ & $100 \%$ \\
\hline 2 & $14 \%$ & $54 \%$ & 236 & 295 \\
\hline 3 & 14 & $14 \%$ & $80 \%$ & $100 \%$ \\
\hline & $5 \%$ & 38 & 242 & 295 \\
\hline & $6 \%$ & $13 \%$ & $83 \%$ & $100 \%$ \\
\hline & 14 & 112 & 171 & 295 \\
\hline A.Faktor External & Tidak Setuju & Netral & Setuju & Sampel/Prosen \\
\hline 1 & 118 & 73 & 118 & 295 \\
\hline
\end{tabular}




\begin{tabular}{|c|c|c|c|c|}
\hline 2 & 171 & 76 & 88 & 295 \\
\hline & $58 \%$ & $26 \%$ & $30 \%$ & $100 \%$ \\
\hline \multirow[t]{3}{*}{3} & 112 & 91 & 88 & 295 \\
\hline & $38 \%$ & $31 \%$ & $30 \%$ & $100 \%$ \\
\hline & 194 & 64 & 56 & 295 \\
\hline 4 & $66 \%$ & $22 \%$ & $19 \%$ & $100 \%$ \\
\hline \multirow[t]{3}{*}{5} & 73 & 165 & 56 & 295 \\
\hline & $25 \%$ & $56 \%$ & $19 \%$ & $100 \%$ \\
\hline & 11 & 132 & 141 & 295 \\
\hline \multirow[t]{2}{*}{6} & $4 \%$ & $45 \%$ & $48 \%$ & $100 \%$ \\
\hline & 50 & 140 & 112 & 295 \\
\hline \multirow[t]{2}{*}{7} & $17 \%$ & $49 \%$ & $34 \%$ & $100 \%$ \\
\hline & 53 & 67 & 171 & 295 \\
\hline \multirow[t]{2}{*}{8} & $18 \%$ & $23 \%$ & $58 \%$ & $100 \%$ \\
\hline & 17 & 97 & 179 & 295 \\
\hline \multirow[t]{2}{*}{9} & $6 \%$ & $33 \%$ & $61 \%$ & $100 \%$ \\
\hline & 26 & 179 & 88 & 295 \\
\hline \multirow[t]{2}{*}{10} & $9 \%$ & $61 \%$ & $30 \%$ & $100 \%$ \\
\hline & 61 & 127 & 107 & 295 \\
\hline \multirow[t]{2}{*}{11} & $21 \%$ & $43 \%$ & $36 \%$ & $100 \%$ \\
\hline & 14 & 159 & 120 & 295 \\
\hline \multirow[t]{2}{*}{12} & $5 \%$ & $54 \%$ & $41 \%$ & $100 \%$ \\
\hline & 11 & 150 & 132 & 295 \\
\hline \multirow[t]{2}{*}{13} & $4 \%$ & $51 \%$ & $45 \%$ & $100 \%$ \\
\hline & 6 & 144 & 168 & 295 \\
\hline \multirow[t]{2}{*}{14} & $2 \%$ & $41 \%$ & $57 \%$ & $100 \%$ \\
\hline & 91 & 127 & 77 & 295 \\
\hline \multirow[t]{2}{*}{15} & $31 \%$ & $43 \%$ & $26 \%$ & $100 \%$ \\
\hline & 159 & 103 & 33 & 295 \\
\hline \multirow[t]{2}{*}{16} & $54 \%$ & $35 \%$ & $11 \%$ & $100 \%$ \\
\hline & 197 & 79 & 17 & 295 \\
\hline \multirow[t]{2}{*}{17} & $67 \%$ & $27 \%$ & $6 \%$ & $100 \%$ \\
\hline & 194 & 76 & 23 & 295 \\
\hline \multirow[t]{2}{*}{18} & $66 \%$ & $26 \%$ & $8 \%$ & $100 \%$ \\
\hline & 88 & 85 & 120 & 295 \\
\hline \multirow[t]{2}{*}{19} & $30 \%$ & $29 \%$ & $41 \%$ & $100 \%$ \\
\hline & 85 & 88 & 120 & 295 \\
\hline \multirow[t]{2}{*}{20} & $29 \%$ & $30 \%$ & $41 \%$ & $100 \%$ \\
\hline & 165 & 85 & $41^{\prime}$ & 295 \\
\hline 21 & $56 \%$ & $29 \%$ & $14 \%$ & $100 \%$ \\
\hline
\end{tabular}

Sumber : Hasil Angket 2017

\section{Analisis Faktor Internal}

1. Pernyataan 1 adalah : Sejak awal saya ingin kuliah di STEI 
2. Ternyata yang menjawab yaitu $54 \%$ adalah netral, dan yang betul betul dari awal ingin kuliah di STEI sebesar $33 \%$ dan yang dari awal tidak ada minat sebesar $13 \%$. Artinya bahwa kuliah di STEI belum menjadi pilihan utama namun pada akhirnya keputusan untuk kuliah memilih di STEI.

3. Pernyataan 2 adalah : Saya bercita-cita ingin menjadi sarjana ekonomi

4. Responden yang berkeinginan menjadi sarjana ekonomi ternyata sebanyak $80 \% .14 \%$ netral dan $5 \%$ tidak berminat menjadi sarjana ekonomi. Jadi mahasiswa STEI dominanbercita-cita menjadi sarjana ekonomi

5. Pernyataan 3 adalah : Dengan kuliah di STEI ingin memperoleh pekerjaan yang baik Responden sebesar $83 \%$ dengan kuliah di STEI ini berharap akan mendapatkan pekerjaan yang baik kelak ketika sudah lulus sebanyak $13 \%$ netral dan hanya $2 \%$ tidak mengejar pekerjaan yang baik. Responden berkeyakinan bahwa lulusan STEI akan memperoleh pekerjaan baik.

6. Pernyataan 4 adalah : Saya merasakan ada bakat saya bidang ekonomi

7. Responden memiliki bakat di bidang ilmu ekonomi, hasil angketnya adalah $58 \%$ merasakan memiliki bakat bidang ekonomi, $38 \%$ netral dan hanya $5 \%$ merasakan tidak ada bakat dalam bidang ilmu ekonomi. Jadi mahasiswa STEI merasa berbakat di bidang ilmu ekonomi.

\section{Analisis Faktor Eksternal}

1. Pernyataan 1 adalah : Saya kuliah di STEI atas saran orang tua

2. Orang tua yang menyarankan anaknnya studi di stei sebanyak $34 \%$, netral $25 \%$ dan $40 \%$ orang tua tidak memberi saran, semua dipertimbangkan oleh anaknya sendiri. Angka ini imbang jadi banyak yang masuk karena di sarankan oleh orang tuanya sedangkan netral dan keputusan sendiri adalah wajar karena banyak yang kuliah di STEI yang sudah mendapatkan pekerjaan sehinggga keputusan lebih mandiri.

3. Pernyataan 2 adalah : Saya kuliah di STEI atas saran dari alumni

4. Responden masuk stei yang disarankan oleh alumni sebanyak $15 \%$, netral $26 \%$ dan tidak disarankan oleh alumni sebanyak $58 \%$. Jadi mayoritas masuk stei tidak atas saran dari alumni. Alumni yang bertebaran di seluruh Indonesia menjadi hambatan untuk menyarankan calon mahasiswa kuliah di STEI.

5. Pernyataan 3 adalah : Saya kuliah di STEI atas saran dari teman

6. Saran dari teman baik di sekolah asal maupun lingkungan dengan jumlah $30 \%$ disarankan teman, $31 \%$ netral dan $38 \%$ tidak mendapatkan saran dari teman responden. Jadi terdapat 
jumlah yang berimbang antara penerima saran, tidak disarankan dan netral. Walaupun tipis tetap mayoritas adalah tidak atas saran dari teman.

7. Pernyataan 4 adalah : Saya kuliah di STEI atas saran Guru waktu SMA/SMK

8. Sebagai sumber informasi juga didapatkan dari para guru di sekolah SMA/SMK namun hasilnya tidak besar yaitu $21 \%$ mendapatkan saran, $22 \%$ netral dan sebanyak $66 \mathrm{k} \%$ kuliah di STEI tidak atas dasar saran dari guru sekolahnya.

9. Pernyataan 5 adalah kuliah di STEI karena fasilitasnya lengkap

10. STEI memiliki fasilitas pendidikan yang lengkap dengan perolehan jumlah $19 \%$ memandang STEI fasilitasnya lengkap, $56 \%$ netral dan $25 \%$ fasilitas yang dimiliki STEI tidak lengkap.. Hanya $19 \%$ yang menyatakan fasilitas STEI lengkap artinya sudah tahu lebih dulu informasi dari keluarga Civitas Akademi STEI.

11. Pernyataan 6 adalah Kuliah di STEI karena Akreditasinya B (Baik)

12. Faktor akreditasi menjadi pertimbangan kuliah di STEI yaitu sebanyak $48 \%$ menyatakan Setuju, $45 \%$ netral dan hanya $4 \%$ saja yang Tidak Setuju akreditasi STEI. Jadi mayoritas menjadi pertimbangan masuk STEI karena akreditasi STEI adalah B (Baik).

13. Pernyataan 7 adalah Kuliah di STEI karena proses belajar mengajar STEI baik

14. Faktor proses belajar mengajar di STEI ternyata mayoritas netral $49 \%$, sebanyak $34 \%$ karena proses belajar mengajar baik, dan $17 \%$ tidak melihat proses belajar mengajar baik di stei. Jadi yang mengetahui bahwa proses belajar mengejar (PBM) di STEI baik cukup tinggi yaitu sebanyak $34 \%$, walaupun mereka belum kuliah di STEI tetapi informasi telah beredar di masyarakat STEI PBMnya baik.

15. Pernyataan 8 adalah Kuliah di STEI karena tidak jauh dari lokasi rumah

16. Ternyata dominan karena faktor lokasi yaitu sebanyak $58 \%$ kuliah di stei karena lokasi dekat dengan kampus. $23 \%$ netral dan hanya $18 \%$ memberi jawaban kuliah stei bukan karen lokasi. Jadi faktor lokasi sangat dominan mencapai $58 \%$ calon mahasiswa memilih kuliah STEI yaitu di seputar wilayah Rawamangun.

17. Pernyataan 9 adalah Kuliah di STEI karena uang kuliah terjangkau dibanding kampus lain yang ada di Jakarta

18. Pertimbangan uang kuliah yaitu $60 \%$ kuliah di stei karena biaya murah, $33 \%$ netral dan hanya $5 \%$ yang tidak masalah untuk kuliah di STEI. Faktor uang kuliah sangat signifikan mencapai $60 \%$ mahasiswa memilih kuliah di STEI karena uang kuliah terjangkau. Besarnya uang kuliah di STEI antara 4 juta hingga 5 juta per semester. Uang kuliah tersebut memang paling rendah di bandingkan dengan perguruan tinggi swasta lain yang setingkat. 
19. Pernyataan 10 : Kuliah di STEI kegiatan kamahasiswaannya baik dan banyak

20. Responden melihat pertimbangan kegiatan kemahasiswaan dengan pilihan yaitu $30 \%$ karena kegiatannya menarik, $61 \%$ netral dan hanya $9 \%$ yang mempertimbangkan kegiatan mahasiswa STEI. Kegiatan kemahasiswaan STEI seperti sering jadi juara di bidang olah raga, seni budaya, seminar, pencinta alam dan sebagainya, ternyata kegiatan tersebut hanya mendorong $30 \%$ calon mahasiswa sebagian besar mahasiswa masuk kuliah di STEI bukan karena kegiatan kemahasiswaan.

21. Pernyataan 11 : Saya memilih STEI karena sesuai penghasilan orang tua

22. Respoden memilih STEI disesuaikan dengan penghaslan orang tua yaitu $34 \%$ sesuai atas penghasilan oang tua, $41 \%$ netral dan $19 \%$ masuk stei tidak atas dasar penghasilan oang tua. Dengan demikian maka mayoritas tidak terkait dengan panghasilan orang tua.

23. Pernyataan 12 adalah : Masuk STEI karena citra atau nama baik STEI baik

24. Responden memiliki kesan citra STEI baik yaitu $41 \%$, $54 \%$ netral dn hanya $5 \%$ nama baik tidak menjadi pertimbangan. Calon Mahasiswa STEI masuk karena Citra Positif $41 \%$. Sedangkan yang dominan adalah netral artinya tidak tahu nama baik atau image STEI.

25. Pernyataan 13 adalah : Masuk STEI karena Dosen STEI berkualitas baik

26. Sebanyak $44 \%$ masuk STEI karena kwalitas dosen STEI baik, $51 \%$ netral dan hanya $4 \%$ yang tidak karena kwalitas dosen STEI. Mayoritas mengisi netral artinya belum tahun kwalitas dosen baik atau buruk.

27. Pernyataan 14 adalah : Kuliah di STEI karena mutu pendidikannya baik

28. Sebanyak $57 \%$ memandang mutu pendidikan baik, $41 \%$ netral dan hanya $2 \%$ tidak mempertimbangkan mutu pendidikan STEI. Hal ini menunjukan sangat signifikan mayoritas menyatakan STEI perguruan tinggi bermutu mencapai $57 \%$ responden. Jadi STEI sudah populer adalah perguruan tinggi bermutu..

29. Pernyataan 15: Saya memilih STEI karena Mengetahui STEI dari Internet

30. Sebagai sumber informasi $25 \%$ informasi dari internet, $43 \%$ netral dan sebanyak $31 \%$ tidak menggunakan internet. Efektifitas internet paling rendah yaitu hanya $25 \%$. Cocok bahwa mayoritas Mahaiswa STEI karena dekat lokasi STEI.

31. Pernyataan 16 : memilih STEI karena mengetahui dari iklan/berita koran

32. Pengaruh iklan STEI di koran $11 \%$, netral sebanyak $35 \%$ dan sebanyak $54 \%$ iklan STEI di koran tidak mempengaruhinya mungkin juga tidak pernah melihatnya. Jadi secara langsung dampak iklan di koran adalah kecil menentukan pilihan untuk kuliah di STEI.

33. Pernyataan 17 : Dampak radio yaitu hanya $5 \%$ yang mendapat informasi dari radio, $26 \%$ netral dan sebanyak $67 \%$ tidak menerima informasi dari radio. Jadi dampak iklan atau 
berita STEI di radio untuk mendorong kuliah di STEI paling rendah yaitu hanya $5 \%$, sebagian besar tidak menerima informasi dari radio.

34. Pernyataan 18 adalah : Saya memilih STEI karena informasi dari TV

35. Dampak televisi sebanyak $5 \%$ dari televisi, $27 \%$ netral dan tidak melihat televisi sebanyak $67 \%$ artinya tidak menerima informasi dari televisi. Jadi sangat kecil sekali pengaruh langsung dari tayangan televisi tentang STEI.

36. Pernyataan 19 adalah Saya memilih STEI karena informasi dari brosur

37. Sebanyak $47 \%$ informasi stei dari brosur, $25 \%$ netral dan $27 \%$ tidak bersumber dari brosur. Artinya bahwa sebagian besar mahasiswa mendapat informasi tentang STEI adalah dari brosur. Brosur disebar ke sekolah-sekolah, pameran dan sebagainya sehinggga menjangkau luas,

38. Pernyataan 20 adalah Saya memilih STEI karena informasi dari spanduk

39. $41 \%$ dapat informasi dari spanduk, 30 netral dan $29 \%$ tidak melihat spanduk. Dengan demikian bahwa mayoritas yang masuk kuliah di stei melihat spanduk. Spanduk Penerimaan Mahasiswa Baru banyak di pasang di sekolah sekolah dan kampus STEI sendiri.

40. Pernyataan 21: memilih STEI karena ada presentase di SMK/SMA dulu

41. Faktor presentasi ke sma atau smk dengan hasil yaitu $14 \%$ pernah menerima informasi di sekolah. $29 \%$ netral dan mayoritas sebanyak $56 \%$ tidak pernah menerima informasi melalui presentasi STEI di sekolah asal. Jadi sebagian besar tidak mendapat presentase dari STEI.

\section{SIMPULAN DAN SARAN}

\section{Simpulan}

1. Berdasarkan hasil penelitian maka dapat disimpulkan adalah sbb:

2. Responden mayoritas dengan kuliah di STEI ini akan mendapatkan pekerjaan yang baik kelak ketika sudah lulus. Jadi sebagian besar responden yakin lulusan STEI akan memperolah pekerjaan yang baik.

3. Mayoritas masuk STEI karena akreditasi STEI adalah B dan dalam memutuskan tempat kuliah mayoritas faktor lokasi yaitu dekat dengan kampus, selain itu karena uang kuliah di STEI terjangkau.

4. Dari ke empat sumber saran yang dominan adalah saran dari orang tua $34 \%$ kemudian 30 $\%$ dari teman. Saran dari Alumni dan Guru agar Calon Mahasiswa kuliah di STEI adalah tidak dominan. 
5. Responden menjawab netral tentang kwalitas dosen yaitu $51 \%$. Kemudian sebanyak $44 \%$ menyatakan dosen stei berkwalitas. Jadi memilih kuliah di STEI karena kwalitas dosen tidak dominan.

6. STEI adalah perguruan tinggi bermutu mencapai $57 \%$. Jadi STEI sudah populer adalah perguruan tinggi bermutu, walaupun calon mahasiswa belum kuliah di STEI tetapi informasi sudah beredar di masyarakat luas bahwa STEI adalah sekolah bermutu.

7. Sebagian besar Calon Mahasiswa STEI menerima informasi dari brosur dan spanduk. Responden sedikit sekali menerima informasi dari iklan di koran, radio, televisi, internet dan presentasi pihak STEI di sekolah.

\section{Saran-saran}

1. Faktor akreditasi sangat dominan Calon Mahasiswa memilih kuliah di STEI. Sehingga Pimpinan STEI perlu upaya yang maksimal untuk meningkatkan akreditasi semua prodi dari B STEI ke A. Usulan akreditasi bisa diajukan setiap saat setelah dua tahun dari penerimaan SK dari BAN-PT.

2. Mayoritas mahasiswa STEI betempat tinggal tidak jauh dari kampus STEI. Untuk itu pendekatan dengan masyarakat sekitar kampus STEI sangat diperlukan, bisa melalui kegiatan pengabdian pada masyarakat, penyuluhan dsb.

3. Uang kuliah jangan terlalu tinggi karena mereka masuk STEI atas biaya kuliah terjangkau. Namun ukurannya bisa survey ke PTS yang setingkat, lalu harga maksimal sama atau sedikit kurang dari harga PTS lain.

4. Dosen STEI perlu sering bergabung dengan masyarakat untuk lebih dikenal dikarenakan mayoritas responden tidak mengenal dosen dengan segala kemampuannya. Kegiatan pengabdian kepada masyarakat harus sering dilakukan sehingga para dosen dapat langsung bertemu dangan maasyarakat.

5. Perlu dipertahankan dan ditingkatkan citra STEI dengan kwalitas pendidikannya karena citra dan kwalitas pendidikan mayoritas dipilih mahasiswa. Membangun citra yaitu dengan berbagai kegiatan seminar, pemberian beasiswa kepada lulusan SMA terbaik.

6. Media yang banyak di ketahui oleh reponden adalah brosur dan spanduk jadi spanduk dan brosur perlu ditingkatkan jumlahnya. Gunakan promosi sepanjang tahun.

7. Memberi informasi ke sekolah SMTA perlu ditingkatkan karena minimnya guru guru di sekolah tentang STEI sehinga jarang sekali siswa dapat informasi dari sekolah asal.

\section{DAFTAR PUSTAKA}


Adrian Payne.(2007). The Essence of Service Marketing (Pemasaran Jasa) Jakarta Salemba Empat

Ali Hasan, S. M. (2008). Marketing. Yogyakarta: Media Pressindo.

Anoraga, Pandji. (2004). Manajemen Bisnis. Cetakan Ke 3. Penerbit Rineka Cipta, Jakarta.

Ari Setyaningrum, Jusuf Udaya, Efendi, (2015) Prinsif-Prinsif Pemasaran, Penerbit Andi, Yogyakarta.

Assauri, Sofjan. , (2010) Manajemen Pemasaran. Jakarta: Rajawali Press

Assael, Henry. (1998). Consumer Behaviour and Marketing Action, 6th Edition International Thompson Publishing, New York

Altman, I. \& Taylor, D.A.(2006) Social penetration: The development or interpersonal relationship Holt, Rinehart \& Winston. New York:

Basu Swastha DH., (2000), Asas-asas Marketing, Edisi III, Liberty Yogyakarta

Buchari Alma,. (2005). Manajemen Pemasaran dan Pemasaran Jasa, Cetakan 5. Bandung, CV. Alfabeta.

David wijaya, (2012), Pemasaran Jasa Pendidikan, Salemba Empat, Jakarta:

Danang Sunyoto (2012). Dasar-dasar manajemen pemasaran. Cetakan Pertama. CAPS. Yogyakarta

Djoko Purwanto, (2011), Komunikasi Bisnis, Penerbit Erlangga, Jakarta

Engel, James F., Blackwell, Roger D. \&Miniard, Paul W. (1996). Perilaku Konsumen Alih Bahasa: F. X. Budiyanto, Jilid II, Binarupa Aksara, Jakarta.

Eistein Yazid, (2005), Kimia Fisika Untuk Paramedis, Penerbit Andi, Yogyakarta

Goetsch, D.L. \& Davis, S. (1994). Introduction to Total Quality : Quality, Productivity, Competitiveness. Englewood Cliffs, NJ : Prentice Hall International, Inc.

Girard, Joe, (2015), 13 aturan penting dalam penjualan, (terjemahan) Penerbit PT Gramedia Pustaka Utama, Jakarta

Ghozali, Imam. (2006). Aplikasi Analisis Multivariate Dengan Program SPSS.UNDIP Semarang.

Hurriyati, Ratih, (2005). Bauran Pemasaran dan Loyalitas Konsumen, Alfabeta, Bandung.

Hoyer and Macinnis. (2006). Consumer Behavior 4 th edition. South-Western, USA

Kasmir, (2014) Kewirausahaan, Rajawali Pers, Jakarta

-, (2004). Bank dan Lembaga Keuangan Lainnya.: PT.Raja Grafindo Persada, Jakarta 
Kismono, Gugup, (2011), Bisnis Pengantar, Edisi Dua, BPFE UGM, Yogyakarta.

Kotler dan Keller, 2012, Marketing Management Edisi 14, Global Edition.Pearson Prentice Hall.

Kotler, Philip dan Gary Armstrong. 2010. Principles of Marketing (Edisi 13). United States of America: Pearson.

Kotler, Philip. (2005) Manajamen Pemasaran, Jilid 1 dan 2.: PT. Indeks Kelompok Gramedia. Jakarta

--------, (2000), Manajemen Pemasaran, PT. Prenhallindo, Jakarta

-----------, (2002) Manajemen pemasaran di Indonesia, Jakarta, Penerbit Erlangga

Lovelock, Christoper dan Lauren Wright. (2005). Manajemen Pemasaran Jasa. Jakarta: PT. Indeks Kelompok Gramedia.

Lupiyoadi, Rambat, (2013), Manajemen Pemasaran Jasa, Salemba Empat Jakarta

Levitt, Thedore. (1987). Imajinasi Pemasaran, Terjemahan. Jakarta Erlangga

Morrison. (2005) Media penyiaran, strategi mengelola radio dan televisi. Ramdina Perkasa, Tangerang:

Maruf, Hendri, (2006), Pemasaran Ritel, Penerbit Gramedia Pustaka Utama. Jakarta:

Mowen, J.C, Minor.M. (1998). Consumer Behavior. New York : Prentice Hall Inc

Monroe, Allard C.R Van Riel et al. (2005). Marketing Antecedent of Industrial Brand Equity An Empirical Investigation in Specialty Chemical

M. Sastrapradja,(1981) Kamus Istilah Pendidikan dan Umum, Surabaya :Usaha Nasional, Surabaya.

Sevilla, Consuelo et, Al. (1993). Pengantar Metode Penelitian. Jakarta : Universitas Indonesia Press.

Schiffman \& Kanuk. (2008). Perilaku Konsumen (edisi 7). Jakarta : Prentice Hall (2004) Perilaku Konsumen (edisi 5). Jakarta : Prentice Hall

Schnaars (1998), Marketing Strategy : Customers and Competitions, 2nd, ed.Ne, New York, The free, Press

Suprapto, dkk. (2007).Pendidikan Kewarganegaraan Kelas X SMA/MA 1, PT Bumi Aksara.Surapranata, Jakarta

Sugiyono. (2011). Metode Penelitian Kuantitatif, kualitatif dan $R \&$ D. Bandung: Penerbit Alfabeta

Sumadi Suryabrata. (1994). Psikologi Pendidikan Penerbit PT Raja Grafindo . Jakarta 
Swasta, Basu dan T Hani Handoko. 2000. Manajemen Pemasaran: Analisa dan Perilaku Konsumen. Yogyakarta: BPFE.

Tjiptono Fandy, (2004), Strategi Pemasaran, edisi kedua, Andi, Yogyakarta. , (1998). Manajemen Jasa, Ed.2. Penerbit Andi, Yogyakarta

Ujang Sumarwan, (2015) Perilaku Konsumen, Penerbit, Ghalia Indonesia, Bogor.

Yazid, (2003), Pemasaran Jasa, Edisi Kedua, Ekonisia Fakultas Ekonomi UII, Yogyakarta

Zeithaml, Valarie A. dan Bitner. 2000. Service Marketing 2nd edition : Integrating Customer Focus. New York : Mc Graw Hill Inc.

M. Nurtanto1 dkk. (2017) Faktor pengaruh minat masuk perguruan tinggi Di smk serang, Jurnal Pendidikan Teknologi dan Kejuruan Vol. 14, No. 1, Januari 2017, Hal : 11 P-ISSN : 02163241 ; E-ISSN : 2541-0652

Santoso, Metha Agus (2008) "Kepuasan terhadap pengajaran yang ditawarkan elemen-elemen baru mutu di perguruan tinggi, Jurnal Manajemen dan Kewirausahaan, No 1 Volume 6, Unveritas Sebelas Maret Surakarta, p 12-24 